\title{
LEX CEU, AVAGY A SZABAD OKTATÁSHOZ VALÓ JOG KÉRDÉSE *
}

\author{
Lovas Dóra
}

2017. április 4-én a magyar parlament 123 igen és 38 nem szavazattal elfogadott egy olyan törvénymódositást, amely sokak szerint a Közép-Európai Egyetem (CEU) ellehetetlenitését célozza. A döntés ellen tüntetések szervezödtek, illetve nemzetközi tiltakozáshullám indult meg. Ebben a bejegyzésben ezt a kérdéskört járom körbe, kitérve csak a leglényegesebb pontokra.

A Közép-európai Egyetem (CEU) nemzetközi posztgraduális felsőoktatási magánintézmény, amelynek központja Budapesten van. Az egyetem alapdiploma utáni mester- és doktori képzéseket nyújt angol nyelven, a társadalomtudományok, a bölcsészettudományok, a közgazdaságtudomány és a jogtudomány területén.

A Közép-európai Egyetem gondolata még 1989 elött született meg. Cél az volt, hogy a régi szocialista országokban egy új, nyugati modellen alapuló egyetemet hozzanak létre, amely ezen országok politikai, társadalmi és gazdasági változásainak elemzésén keresztül a nyitott társadalom értékei felé törekszik. Olyan diákokat akarnak képezni, akik a jövöben tudósként, szakemberként, politikusként vagy a civil társadalom vezetöiként hozzájárulhatnak a nyilt és demokratikus társadalmak létrejöttéhez. A Közép-Európai Egyetem 1991-ben nyilt meg Prágában, majd 1993-ban Budapestre költözött, ezt követően 2004-ben államilag elismert egyetem lett Magyarországon. Jelenlegi rektora Michael Ignatieff. ${ }^{2}$

Magyarországon egy külföldi felsőoktatási intézmény több formában müködhet (5 módja van: magyarországi működési engedéllyel, határon átnyúló szolgáltatásnyújtással, magyar felsőoktatási intézményen keresztül licencia képzés indításával, magyar felsőoktatási intézménnyel együttmüködésben közös képzés folytatásával, valamint magyar felsőoktatási intézménnyel együttmüködésben kettős képzés folytatásával).A CEU müködési engedély alapján végzi oktatási tevékenységét, amelyre vonatkozóan a Nemzeti Felsőoktatásról szóló törvény 3 követelményt állapít meg: az intézményt a származási országban ismerjék el, mint felsőoktatási intézményt; a Magyarországon végezni kívánt tevékenység államilag elismert legyen, valamint az Oktatási Hivatal által engedélyezett tevékenységről legyen szó. ${ }^{3}$

A Nftv. szerint az Oktatási Hivatal a külföldi felsőoktatási intézmények müködési engedélyét legalább ötévente köteles felülvizsgálni. ${ }^{4}$ A Hivatal 2016 nyarán (elöször) kezdte el a Magyarországon müködési engedéllyel rendelkező külföldi felsőoktatási intézmények engedélyének felülvizsgálatát. ${ }^{5}$ A kérdéses intézmények a következők:

\footnotetext{
* DOI 10.21867/KjK/2017.1.2.

${ }^{1}$ Dr. Lovas Dóra, PhD hallgató, DE-ÁJK

2 https://www.ceu.edu/

${ }^{3}$ Nemzeti felsőoktatásról szóló 2011. CCIV. törvény (Továbbiakban: Nftv.) $76 \S(1)-(2)$

${ }^{4}$ A nemzeti felsőoktatásról szóló 2011. évi CCIV. törvény egyes rendelkezéseinek végrehajtásáról szóló 87/2015. (IV. 9.) Korm. (Vhr.)

${ }^{5} \mathrm{Nftv} .76 . \S(3)$
} 


\begin{tabular}{|c|c|c|}
\hline & Felsőoktatási intézmény & Székhelyország \\
\hline 1. & Anglia Ruskin University & Egyesült Királyság \\
\hline 2. & $\begin{array}{l}\text { AvansHogeschool International Business } \\
\text { SchoolBreda }\end{array}$ & Hollandia \\
\hline 3. & $\begin{array}{l}\text { Banking Institute College of Banking } \\
\text { (Bankovníinstitutvysokáškola) }\end{array}$ & Cseh Köztársaság \\
\hline 4. & Boston University & Amerikai Egyesült Államok \\
\hline 5. & CECOS London College & Egyesült Királyság \\
\hline 6. & Central European University & Amerikai Egyesült Államok \\
\hline 7. & École d'Art Maryse Eloy & Franciaország \\
\hline 8. & $\begin{array}{l}\text { École Supérieure des } \\
\text { SciencesCommercialesd'Angers }\end{array}$ & Franciaország \\
\hline 9. & Edinburgh Napier University & Egyesült Királyság \\
\hline 10. & Georg-August-Universität Göttingen & Németország \\
\hline 11. & HēilóngjiāngDàxué & Kínai Népköztársaság \\
\hline 12. & $\begin{array}{l}\text { Mahachulalongkornrajavidyalaya } \\
\text { University }\end{array}$ & Thaiföldi Királyság \\
\hline 13. & McDaniel College & Amerikai Egyesült Államok \\
\hline 14. & Middlesex University & Egyesült Királyság \\
\hline 15. & Mod'Art International & Franciaország \\
\hline 16. & Open University Malaysia & Malajzia \\
\hline 17. & Oxford Brookes University & Egyesült Királyság \\
\hline 18. & Universidad de Granada & Spanyolország \\
\hline 19. & $\begin{array}{l}\text { Universitatea de } \\
\text { MedicinăşiFarmacieTârgu-Mureş }\end{array}$ & Románia \\
\hline 20. & Université de Picardie Jules Verne & Franciaország \\
\hline 21. & Université Pantheton-Assas (Paris II) & Franciaország \\
\hline 22. & $\begin{array}{l}\text { Université Paris Ouest Nanterre la } \\
\text { Défense }\end{array}$ & Franciaország \\
\hline 23. & University of Buckingham & Egyesült Királyság \\
\hline 24. & University of Hertfordshire & Egyesült Királyság \\
\hline 25. & University of Wales, Newport & Egyesült Királyság \\
\hline 26. & ViennaKonservatorium & Ausztria \\
\hline 27. & Webster University & Amerikai Egyesült Államok \\
\hline 28. & $\begin{array}{l}\text { WyższaSzkołaBezpieczeństwaPubliczne } \\
\text { go i Indyvidualnego „Apeiron” w } \\
\text { Krakowie }\end{array}$ & Lengyelország \\
\hline
\end{tabular}

Forrás: Jelentés a külföldi felsőoktatási intézmények magyarországi müködéséröl(EMMI)

A felülvizsgálat során azonban több jogszabályoknak nem megfelelő müködési problémára derült fény: ${ }^{6}$

\footnotetext{
${ }^{6}$ Jelentés a külföldi felsőoktatási intézmények magyarországi müködéséről (EMMI)
} 
1. A külföldi felsőoktatási intézmény nem a megfelelö jogszabályi keretek között folytatja a képzését, azaz valójában nem müködik Magyarországon, helyette lényegében a magyarországi partnere valósítja meg a képzését vagy annak nagy részét, így sokszor az oktatók jelentős része is magyar. Az ilyen intézménynek valójában nem müködési engedéllyel kellene rendelkeznie, hanem más formában müködnie. Ez pedig a jelentés szerint jogszerütlen helyzetet is teremt, mivel adott külföldi felsőoktatási intézmény mesterképzésén olyan magyarországi hallgatók is részt vesznek, akik nem rendelkeznek alapfokozattal. A másik jellemző eset, amikor a magyar felsőoktatási felvételi eljárásban felvételt nem nyert hallgatókat gyüjt össze a külföldi felsőoktatási intézmény a képzésére, akik utána egy vagy néhány félévvel később átvétellel kerülnek be az magyar felsőoktatási intézménybe.

\section{Nincs együttmüködés és magyarországi partner}

Gyakran ezek az intézmények nem is folytatnak oktatási tevékenységet, mégsem kérik az engedély visszavonását. Erre volt példa az Université Paris Ouest Nanterre la Défense.

\section{Hiányzik a programakkreditáció}

Az angolszász államokban és a legtöbb ázsiai országban jellemző, hogy nem kötelező a felsőoktatási intézmény képzése folytatásának a független külső felsőoktatási akkreditációs ügynökség / szervezet általi programakkreditáció. Például a Central European University (belső intézményi audit), amelynél a Middle States Commissionon Higher Education követelményrendszere komoly feltételeket jelent, amelyeket a CEUnak korábban is teljesítenie kellett és a jövőben is teljesítenie kell ahhoz, hogy akkreditált felsőoktatási intézmény lehessen az Amerikai Egyesült Államokban. Ilyen elemek például: az oktatási potenciál bizonyítása különböző módokon, ezáltal a kurzusok biztosítására és az egyéb akadémiai felelősség vállalására való alkalmasság; fokozathoz vezető képzések esetében valamennyi képzésben oktatónak a releváns területen tudományos fokozattal (doktorátussal) kell rendelkeznie; legyen valamennyi oktatónak és kutatónak időszakonkénti rendszeres értékelése az intézmény által; szigorúan kontrollálnia kell az intézménynek a felvételt, hogy az egyes programokra a megfelelö elöképzettségü hallgatók jussanak be.

Az Egyesült Királyságban az University of Buckingham, az Oxford Brookes University, illetve a Hēilóngjiāng Dàxué, Heilongjiang Kínai Orvostudományi Egyetem esetében a magyar jogszabály által kért külső szakakkreditáció nem müködési feltétel (intézményszintű akkreditáció).

\section{A külföldi felsőoktatási intézmény által kiállított okirat nem államilag elismert (fokozatot adó) oklevél}

A Magyar Ekvivalencia és Információs Központ (MEIK) állásfoglalása alapján a Mod'Art International (Franciaország), az École d'Art Maryse Eloy (Franciaország) és a Vienna Konservatorium külföldi felsőoktatási intézmények által kiállított okirat nem államilag elismert oklevél, továbbá nem tanúsít a felsőoktatási fokozatrendszer szerinti fokozatot. 


\section{A külföldi felsőoktatási intézmény nem minösül származási országában államilag elismert felsőoktatási intézménynek}

\section{A közhiteles nyilvántartásba történő adatszolgáltatási kötelezettség nem teljesül}

A 2016. december 31-i állapot szerint 28 külföldi felsőoktatási intézmény rendelkezett Magyarországon működési engedéllyel, amelyből 5 szolgáltatott adatot. ${ }^{7}$

\section{A külföldi felsőoktatási intézmény nyilvántartásba nem vetetett képzéseket folytat}

A jelentés szerint a McDaniel College (USA) az egyetlen magyarországi müködési engedéllyel rendelkező külföldi felsőoktatási intézmény, amellyel kapcsolatban nem merült fel probléma.

\section{De miért nevezik Lex CEU-nak?}

A 2016-os felülvizsgálat az alábbi hiányosságokat tárta fel az intézményben (adminisztratív problémák):

- Nem rendelkezik programakkreditációval, de ez már hiánypótlás alatt van (USA-ban nem akkreditációnak, hanem regisztrációnak nevezik, általában szigorúbbak is a magyar eljárásnál).

- Nem szolgáltatott adatokat a Felsőoktatási Információs Rendszernek, azonban ezt csak állami intézményeknek kell (a CEU nem az).

- Nyilvántartásba nem vetetett képzésekkel rendelkezik, azonban a CEU 37 képzésének elismerését benyújtotta, 17 másikat pedig pótolni fog.

Összességében tehát megállapítható, hogy az Oktatási Hivatal felülvizsgálata több hibát (a leggyakoribbak: nem jelentettek be adatot, képzéseket nem vettek nyilvántartásba), tárt fel egyes intézményeknél, így a CEU-nál is, de ahogy azt a fentiek igazolják, csak adminisztratív jellegü problémákról van szó, amelyeket az intézmény már orvosolt vagy annak megoldása folyamatban van.

2017. április 4-én a magyar parlament 123 igen és 38 nem szavazattal elfogadta a Nftv. módosítását. Ez a 28 nemzetközi felsőoktatási intézmény közül a CEU-t érinti a leghátrányosabban.

A parlamenti többség véleménye szerint nem igazságos a magyar egyetemekkel szemben, hogy e külföldi intézmény Magyarországi müködése során két diplomát bocsáthat ki (magyar, USA), így versenyelőnyt biztosítva magának a többiekkel szemben.

Ebben az összefüggésben azonban felmerül a magyar egyetemekhez képest a Nemzeti Közszolgálati Egyetem versenyelőnye is, amelyet pedig maga a Parlament biztosított számára, azzal, hogy bizonyos szakok csak itt müködhetnek. De akkor hol itt az igazság? Van akinek lehet és van akinek nem engedjük meg?

Az elfogadott törvény módosítás több újabb követelményt fogalmaz meg a CEU müködési engedély megszerzéséhez:

\section{Kétoldalú szerződés megléte (Magyarország és USA)}

\footnotetext{
${ }^{7}$ Nftv. 19. § (3)
} 
A két ország között megkötendő nemzetközi szerződés kérdése problémás. Ennek oka, hogy az új törvény szerint a szövetségi kormánnyal kellene azt megkötni, holott az USA-ban az oktatás kizárólagos tagállami hatáskör.

\section{Kötelezték az egyetemet, hogy hozzon létre egyetemi campust New York államban}

A CEU a 28 felsőoktatási intézmény közül az egyetlen olyan egyetem, amelynek nincs oktatási tevékenysége az anyaországában (rendkívül költséges lenne), de ad ki ottani diplomát. Az intézmény létrehozásának alapja az volt, hogy összekötetést jelentsen a volt szovjet országok és az Egyesült Államok között, illetve amerikai színvonalú oktatást nyújtson Európában.

A probléma a magyar törvényhozás szerint ezzel kapcsolatban az, hogy annak ellenére, hogy nem oktat az USA-ban, magyar és amerikai diplomát is ad. (Ez persze előnyhöz juttatja a tehetséges magyar diákokat, mert jó egyetemen amerikai diplomát szerezni nagyon drága lenne.)

\section{Az ide utazó tanárok munkavállalási engedéllyel oktathatnak}

Eddig az EBESZ országaiból érkező tanároknak nem kellett munkavállalási engedélyt szereznie (mostantól ez csak az Európai Unió tagállamaira érvényes). Érdekes, hogy egyedül az USA tagja az EBESZ-nek,de az EU-nak nem és a CEU-ra a legtöbb tanár Amerikából jön.

A törvénymódosítás szerint 2018. január elsejétől a nemzetközi felsőoktatási intézmények a jelenlegi rendszer szerint nem vehetnek fel diákokat, de a most futó képzéseket még befejezhetik.

A CEU véleménye szerint a jogszabály diszkriminatív, mivel az a 28 egyetem közül őt érinti leghátrányosabban a legtöbb ponton, továbbá sérti az oktatás szabadságát és nem felel meg a törvénykezés szabályainak, mert nem történt meg a megfelelő egyeztetés elötte.

A parlament által elfogadott törvény a köztársasági elnök előtt van aláírás céljából. A döntés ellen tüntetések szerveződtek, illetve nemzetközi tiltakozáshullám indult meg (Pl.: Nyílt levél Nobel-díjas közgazdászoktól, külföldi illetve magyar oktatóktól, szakemberektől, szakkollégiumoktól, MTA-tól), amelyek Áder Jánost arra kérik, hogy ne írja alá a jogszabályt. Hogy mi lesz a történtek kimenetele, az még kérdéses... 